\title{
Simplified production and concentration of HIV-I-based lentiviral vectors using HYPERFlask vessels and anion exchange membrane chromatography
}

\author{
Robert H Kutner*1, Sharon Puthli ${ }^{1}$, Michael P Marino ${ }^{1,2}$ and Jakob Reiser ${ }^{1,2}$
}

Address: ${ }^{1}$ Gene Therapy Program, Vector Core, Louisiana State University Health Sciences Center, New Orleans, LA, USA and ${ }^{2}$ Division of Cellular and Gene Therapies, Office of Cellular, Tissue and Gene Therapies, US Food and Drug Administration, Center for Biologics Evaluation and Research, Bethesda, MD, USA

Email: Robert H Kutner* - rkutne@lsuhsc.edu; Sharon Puthli - sputhli@yahoo.com; Michael P Marino - Michael.Marino@fda.hhs.gov; Jakob Reiser - Jakob.Reiser@fda.hhs.gov

* Corresponding author

Published: 16 February 2009

BMC Biotechnology 2009, 9:10 doi:10.1/86/1472-6750-9-10
Received: 17 September 2008

Accepted: 16 February 2009

This article is available from: http://www.biomedcentral.com/1472-6750/9/10

(c) 2009 Kutner et al; licensee BioMed Central Ltd.

This is an Open Access article distributed under the terms of the Creative Commons Attribution License (http://creativecommons.org/licenses/by/2.0), which permits unrestricted use, distribution, and reproduction in any medium, provided the original work is properly cited.

\begin{abstract}
Background: During the past twelve years, lentiviral (LV) vectors have emerged as valuable tools for transgene delivery because of their ability to transduce nondividing cells and their capacity to sustain long-term transgene expression in target cells in vitro and in vivo. However, despite significant progress, the production and concentration of high-titer, high-quality LV vector stocks is still cumbersome and costly.
\end{abstract}

Methods: Here we present a simplified protocol for LV vector production on a laboratory scale using HYPERFlask vessels. HYPERFlask vessels are high-yield, high-performance flasks that utilize a multilayered gas permeable growth surface for efficient gas exchange, allowing convenient production of high-titer LV vectors. For subsequent concentration of LV vector stocks produced in this way, we describe a facile protocol involving Mustang $Q$ anion exchange membrane chromatography.

Results: Our results show that unconcentrated LV vector stocks with titers in excess of $10^{8}$ transduction units (TU) per $\mathrm{ml}$ were obtained using HYPERFlasks and that these titers were higher than those produced in parallel using regular $150-\mathrm{cm}^{2}$ tissue culture dishes. We also show that up to $500 \mathrm{ml}$ of an unconcentrated LV vector stock prepared using a HYPERFlask vessel could be concentrated using a single Mustang Q Acrodisc with a membrane volume of $0.18 \mathrm{ml}$. Up to $5.3 \times$ $10^{10} \mathrm{TU}$ were recovered from a single HYPERFlask vessel.

Conclusion: The protocol described here is easy to implement and should facilitate high-titer LV vector production for preclinical studies in animal models without the need for multiple tissue culture dishes and ultracentrifugation-based concentration protocols.

\section{Background}

$\mathrm{LV}$ vectors provide powerful tools for transgene delivery into dividing as well as nondividing cells and for long- term transgene expression in target cells in vitro and in vivo. Currently, the use of LV vectors is commonplace and applications in the fields of neuroscience, hematology, 
developmental biology, stem cell biology and transgenesis have emerged [1]. LV vectors are also being pursued in a number of clinical trials (see http://www.gemc ris.od.nih.gov/). Despite significant progress, the production and concentration of high-titer, high-quality LV vectors for preclinical studies in animal models is still cumbersome and costly [2].

The production of LV vectors is typically carried out using transient transfection approaches involving tissue culture dishes or flasks [3], cell factories [4-6], or stirred-tank bioreactors [7]. These protocols are cumbersome to scale up (dishes, flasks) or technically challenging (cell factories, bioreactors), preventing their routine use in a standard laboratory setting.

Typical LV vector titers involving the vesicular stomatitis virus (VSV) G glycoprotein range from $10^{6}$ to $10^{8} \mathrm{TU} / \mathrm{ml}$ [8]. Higher titers can be achieved by physical concentration [2], including ultracentrifugation [3,9-11], or filtration approaches such as ultrafiltration $[3,10,12-14]$, and diafiltration $[4,6]$. Vector production for large-scale in vivo applications in animal models requiring high-titer LV vector stocks is challenging due to the lack of simple procedures allowing rapid processing of large volumes of LV vector-containing cell culture supernatants. The traditional ultracentrifugation-based methods are limited in terms of their capacity to handle large volumes, thus making this procedure extremely tedious. Filtration approaches such as diafiltration are well suited for processing large volumes of vector supernatants. However, they are difficult to implement in a standard laboratory setting. Thus, there is an emerging need for simple and less laborious procedures that result in a rapid reduction of the volume of the cell culture supernatant to be processed without the need for a centrifugation step.

One problem with the centrifugation and filtration-based methods outlined above is that cell-derived components are concentrated along with the vector particles. These have the potential to cause immune and inflammatory responses [15]. For example, concentrated VSV-G-pseudotyped LV vector preparations were shown to be contaminated with tubovesicular structures of cellular origin which carried nucleic acids, including the plasmid DNAs that were used to generate the LV vector stocks. DNA carried by these tubovesicular structures acted as a stimulus for innate antiviral responses, triggering Toll-like receptor 9 and inducing alpha/beta interferon production [16]. Thus, additional steps including chromatography-based methods such as anion exchange chromatography are needed in order to reduce host cell and cell culturederived contaminants from LV vector preparations. Methods based on anion exchange column chromatography of LV vectors pseudotyped with VSV-G $[17,18]$ or the bacu- lovirus GP64 glycoprotein were previously described [19]. However, the yields and purity of the LV vector stocks obtained in this way were not reported.

In an attempt to simplify the production and concentration of LV vectors and to make this approach more reproducible and cost-effective for preclinical studies in animals, we have worked out a facile LV vector production system based on HYPERFlasks. We also implemented a straightforward concentration procedure based on Mustang $Q$ anion exchange membrane chromatography. Mustang Q anion exchange-based chromatography protocols for concentrating/purifying LV vectors were previously reported $[4,20]$. Such vector preparations displayed reduced toxicity compared to vectors concentrated using ultracentrifugation [20], as well as enhanced purity [4].

\section{Results and discussion \\ Simplified production of lentiviral vectors using HYPERFlasks}

With a view toward improving high-titer LV vector production for preclinical studies in animals, we tested the usefulness of HYPERFlask vessels that have a total growth area of $1720 \mathrm{~cm}^{2}$, corresponding to ten standard T175 flasks. HYPERFlasks consist of ten interconnected growth surfaces each containing a membrane pretreated to allow improved cell adherence. The membrane is gas permeable, allowing exchange of oxygen and carbon dioxide through the base of the membrane, resulting in gas exposure to a large surface area within the flask [21].

To test the usefulness of HYPERFlasks for LV vector production involving calcium phosphate-mediated transfection [10], we compared the titers of LV vector stocks prepared side-by-side using either ten $150-\mathrm{cm}^{2}$ dishes or a single HYPERFlask. The data shown in Table 1 represent the results of three independent productions each for the $150-\mathrm{cm}^{2}$ dish system and the HYPERFlask system. These data indicate that the titers of unconcentrated $\mathrm{LV}$ vectors produced using HYPERFlasks were up to $2.3 \times 10^{8} \mathrm{TU} / \mathrm{ml}$ while the titers of $\mathrm{LV}$ vectors produced in $150-\mathrm{cm}^{2}$ dishes were lower, up to $6.9 \times 10^{7} \mathrm{TU} / \mathrm{ml}$. The total yields were up to $1.2 \times 10^{10} \mathrm{TU}$ from ten $150-\mathrm{cm}^{2}$ dishes and up to 1.3

\begin{tabular}{|c|c|c|}
\hline Production vessels & $\mathrm{TU} / \mathrm{ml}$ & Total TU \\
\hline $150-\mathrm{cm}^{2}$ dishes & $5.6 \pm 1.3 \times 10^{7}$ & $9.5 \pm 2.1 \times 10^{9}$ \\
\hline HYPERFlask & $2.0 \pm 0.3 \times 10^{8}$ & $1.1 \pm 0.16 \times 10^{11}$ \\
\hline
\end{tabular}

Ten $150-\mathrm{cm}^{2}$ dishes (total volume: $170 \mathrm{ml}$ ) and one HYPERFlask vessel (volume: $550 \mathrm{ml}$ ) were used for LV vector production. Productions were performed side-by-side $(n=3)$. Vector titers were determined using HOS cells. Data are expressed as the mean \pm standard deviation (SD). 
$\times 10^{11} \mathrm{TU}$ for the HYPERFlask vessels. This corresponds to a productivity of up to $8 \times 10^{6}$ TU per $\mathrm{cm}^{2}$ for the $150-\mathrm{cm}^{2}$ dishes. For the HYPERFlask, the productivity was about 10 -fold higher, up to $0.75 \times 10^{8} \mathrm{TU}$ per $\mathrm{cm}^{2}$. The higher productivity observed with HYPERFlasks may be related to better gas exchange during LV vector production. Overall, the 293T cells used for production appeared healthier and there was less cell debris from transfections carried out in HYPERFlaks compared to transfections carried out in $150-\mathrm{cm}^{2}$ dishes (data not shown). We expect the HYPERFlask production protocol described here to be compatible with other DNA transfection formats such as polyethylenimine-mediated transfection [22].

\section{Simplified concentration of lentiviral vectors using Mustang Q Acrodiscs}

The concentration and purification of LV vector stocks on a large scale presents a significant bottleneck and methods allowing rapid processing of large volumes of LV vectorcontaining supernatants are needed. Chromatographybased methods appear to be particularly attractive in this regard [2]. For example, methods to concentrate/purify LV vectors based on anion exchange or affinity chromatography have been established [17-19]. Recently, Segura et al. [7] described an approach involving heparin affinity chromatography to concentrate LV vector particles directly from clarified supernatants. During this step, a recovery of $53 \%$ of infectious LV particles was achieved while $94 \%$ of the impurities were removed. This strategy may ultimately result in vector stocks of improved purity, increased infectivity and reduced toxicity. However, these approaches are cumbersome and difficult to implement in a standard laboratory setting.

We have recently described a facile membrane-based chromatography approach involving Mustang $\mathrm{Q}$ anion exchange chromatography cartridges (Acrodiscs) to purify adenoviral vectors [23]. Mustang Q membranes resulted in high recoveries of infectious viral particles and allowed the processing of adenoviral vector particles from lysates in a fraction of the time required using the traditional cesium chloride-based ultracentrifugation method. Mus- tang $Q$ membranes include a matrix that has a high dynamic binding capacity for adenoviral vectors and is capable of withstanding high flow rates. Other benefits of Mustang Q membrane chromatography cartridges include higher peak resolution at faster flow rates as compared to traditional ion exchange resins. Also, they can easily be adapted to bench-scale work and they are syringe-adaptable. Finally, there is no need for an HPLC setup or a column packing step. In work with LV vectors carried out by us $[20,24]$ and by others [4], Mustang Q-based cartridges were used to concentrate/purify LV vectors. While these initial studies were encouraging, the capacity of Mustang Q membranes for crude LV vector supernatants was rather low [24], possibly caused by cell-derived proteins, serum proteins, or contaminating nucleic acids that bound to Mustang Q membranes during vector capturing.

To determine the binding capacity of Mustang Q membranes for $\mathrm{LV}$ vectors produced in HYPERFlask vessels compared to $150-\mathrm{cm}^{2}$ dishes, a capture study was conducted. Figure 1 shows a typical elution profile of HYPERFlask-produced LV vectors following capturing onto a 0.18-ml Mustang Q Acrodisc and elution using a gradient ranging from 0.3 to $1.5 \mathrm{M} \mathrm{NaCl}$. TU were determined by FACS analysis of transduced HOS cells. The results presented in Table 2 show that the capacity of Mustang Q Acrodiscs at $10 \%$ breakthrough for LV vector supernatants produced in $150-\mathrm{cm}^{2}$ dishes was up to $3.9 \times 10^{9} \mathrm{TU}$ per $\mathrm{ml}$ of membrane while the capacity of Mustang $Q$ membranes at $10 \%$ breakthrough for HYPERFlask vesselderived LV vector samples was up to $9.6 \times 10^{10}$ TU per ml of membrane. This is consistent with the observation that LV vector supernatants produced using HYPERFlasks contained fewer cellular proteins and nucleic acids compared to supernatants produced in $150-\mathrm{cm}^{2}$ dishes (Table 3 ) that may have interfered with the binding of the LV vector particles. To remove excess $\mathrm{NaCl}$, pooled Mustang $\mathrm{Q}$ fractions were subjected to a buffer exchange using Sepharose CL-4B. Table 4 summarizes the recovery of LV vectors following processing of 500-ml aliquots of HYPERFlask vessel-derived supernatants. Up to $4.7 \times 10^{10}$ TU were obtained after Mustang Q chromatography and up to 5.3

Table 2: Capacity of Mustang Q Acrodiscs for crude lentiviral vector stocks

\begin{tabular}{|c|c|c|c|c|c|c|}
\hline Production vessels & Input (TU) & Unbound (TU) & Bound (TU) & Recovered (TU) & Yield & Capacity of Acrodisc (TU/ml) \\
\hline $150-\mathrm{cm}^{2}$ dishes & $1.2 \pm 0.5 \times 10^{9}$ & $6.4 \pm 5.1 \times 10^{8}$ & $5.5 \pm 1.6 \times 10^{8}$ & $3.2 \pm 0.8 \times 10^{8}$ & $28.9 \pm 5.4 \%$ & $3.0 \pm 0.9 \times 10^{9}$ \\
\hline HYPERFlask & $1.6 \pm 0.1 \times 10^{10}$ & $2.8 \pm 6.4 \times 10^{8}$ & $1.6 \pm 1.6 \times 10^{10}$ & $1.2 \pm 0.1 \times 10^{10}$ & $76.0 \pm 0.70 \%$ & $\geq 8.7 \pm 0.9 \times 10^{10}$ \\
\hline
\end{tabular}

Mustang Q Acrodiscs were challenged with 75-ml aliquots of vector-containing supernatants. The crude vector supernatants were filtered using a $0.45 \mu \mathrm{m}$ filter prior to anion exchange chromatography on Mustang Q Acrodiscs. Input corresponds to the total number of TU loaded. Unbound corresponds the total number of TU found in the flow-through. Bound represents input TU minus unbound TU. Recovered corresponds to the total number of TU following elution. Capacity corresponds to the total number of TU bound per $\mathrm{ml}$ of the Mustang $\mathrm{Q}$ membrane. Since the HYPERFlask-derived samples did not result in greater than $10 \%$ breakthrough, the upper limit of the capacity for these samples is not known. Titers were determined by FACS using HOS cells. Data from three independent experiments involving 150 - $\mathrm{cm}^{2}$ dish-derived and HYPERFlask vesselderived vector supernatants are shown. The data are expressed as mean \pm SD. 
Table 3: Protein and DNA concentrations for crude lentiviral vector stocks

\begin{tabular}{lll}
\hline Production vessels & Protein $(\mathrm{mg} / \mathrm{ml})$ & DNA $(\mu \mathrm{g} / \mathrm{ml})$ \\
\hline I50-cm ${ }^{2}$ dishes & $4.35 \pm 0.25$ & $11.17 \pm 1.6$ \\
HYPERFlask & $3.03 \pm 0.07$ & $7.22 \pm 0.32$
\end{tabular}

Protein and DNA concentrations of $150-\mathrm{cm}^{2}$ dish-derived and HYPERFlask vessel-derived vector supernatants were determined using a Qubit assay kit (Invitrogen). Productions were performed side-by-side $(n=3)$. Data are expressed as mean $\pm S D$.

$\times 10^{10} \mathrm{TU}$ after subsequent buffer exchange using Sepharose CL-4B (Table 4).

Finally, we wanted to compare the titers and total yields of our concentrated LV vectors with those reported by other groups. To do this, we carried out a side-by-side titer comparison of a HYPERFlask-derived LV vector stock concentrated by Mustang Q anion exchange chromatography using HOS cells, 293T cells and HeLa cells. Table 5 shows that the titers of fresh (unfrozen) vector stocks were similar in HOS cells and 293T cells and slightly lower in Hela cells. Upon freezing and thawing of Mustang Q-concentrated vector stocks there was a $40 \%$ drop in vector titers on average (data not shown).

Overall, the titers obtained using the HYPERFlask system were as high or higher compared to those obtained using $150-\mathrm{cm}^{2}$ dishes and ultracentrifugation-based concentration approaches [3]. The yield (total TU) from a single HYPERFlask (cell growth area: $1720 \mathrm{~cm}^{2}$ ) was above $10^{11}$ TU (Table 1). This is about two orders of magnitude higher than the yields reported by Karolewski et al. [5] who used a cell factory system (total cell growth area: $6320 \mathrm{~cm}^{2}$ ), and at least one order of magnitude higher than the yields reported by Geraerts et al. 2005 [6] who also used Cell Factories.

\section{Conclusion}

In conclusion, we present here a simple protocol for LV vector production and concentration involving HYPERFlasks in conjunction with Mustang Q anion exchange membrane cartridges. These protocols are easy to implement in a standard laboratory setting and allow high-titer $\mathrm{LV}$ vector production without the need for multiple tissue culture dishes or flasks or ultracentrifugation-based concentration procedures.

\section{Methods \\ Cell lines}

293T cells (CRL-11268), human osteosarcoma (HOS) cells (CRL-1543) and HeLa cells (CCL-2) were obtained from the American Type Culture Collection (ATCC) and propagated in DMEM (high glucose), 10\% fetal bovine serum (FBS, Invitrogen-GIBCO), 1\% GlutaMAX (Invitrogen), $1 \%$ Pen/Strep (Invitrogen).

\section{Production of lentiviral vectors using $150-\mathrm{cm}^{2}$ dishes}

$\mathrm{LV}$ vectors were generated by calcium phosphate-mediated transfection of $293 \mathrm{~T}$ cells as described $[10,25]$, with modifications. $293 \mathrm{~T}$ cells were plated in $150-\mathrm{cm}^{2}$ dishes at a density of $8 \times 10^{6}$ cells per dish in $25 \mathrm{ml}$ DMEM medium supplemented with 10\% FBS, 1\% Pen/Strep, 0.3\% HyQ CelPro-LPS (HyClone). Twenty four h later, chloroquine (Sigma-Aldrich) was added to the medium at a final concentration of $25 \mu \mathrm{M}$. LV vector, packaging (helper), and envelope plasmid DNAs were combined in $3 \mathrm{ml}$ of $0.25 \mathrm{M}$ $\mathrm{CaCl}_{2}$ and then mixed with $3 \mathrm{ml}$ of $2 \times$ HEPES-buffered saline $(2 \times$ HBS $)[26]$ using gentle vortexing. The DNA/ $\mathrm{CaCl}_{2} / \mathrm{HBS}$ mixture was then added to medium. The amount of plasmid DNA used per dish was $21 \mu \mathrm{g}$ of the pNL-EGFP/CMV/WPRE $\Delta$ U3 LV vector plasmid DNA [20] (Addgene plasmid 17579), $14 \mu \mathrm{g}$ of the $\mathrm{pCD} / \mathrm{NL}-\mathrm{BH}^{*} \Delta \Delta \Delta$ packaging plasmid DNA [27] (Addgene plasmid 17531) and $7 \mu \mathrm{g}$ of the VSV-G-encoding pLTR-G plasmid DNA [12] (Addgene plasmid 17532). The medium was removed $16 \mathrm{~h}$ later and replaced with $17 \mathrm{ml}$ of fresh DMEM/10\% FBS/1\% GlutaMAX per plate. Forty eight $h$ later, the vector-containing medium was collected and spun at $500 \times \mathrm{g}$ for $5 \mathrm{~min}$, filtered through a $0.45-\mu \mathrm{m}$ pore size filter (Corning) and stored at $-80^{\circ} \mathrm{C}$.

\section{Production of lentiviral vectors using HYPERFlask vessels} 293 T cells $\left(2 \times 10^{8}\right.$ cells $)$ were seeded into a HYPERFlask Cell Culture Vessel (Corning) in $550 \mathrm{ml}$ of DMEM medium supplemented with $10 \%$ FBS, $1 \%$ GlutaMAX, $1 \%$ Pen/Strep, 0.3\% HyQ CelPro-LPS. Twenty four h later, the medium was removed from the HYPERFlask vessel. Sixty $\mathrm{ml}$ of the medium were discarded, and chloroquine was added to the remaining medium at a final concentration of $25 \mu \mathrm{M}$. LV vector, packaging, and VSV-G plasmid DNAs

Table 4: Recovery of lentiviral vectors following Mustang $Q$ anion exchange chromatography and buffer exchange

\begin{tabular}{|c|c|c|c|c|}
\hline Input (TU) & Unbound (TU) & Bound (TU) & $\begin{array}{l}\text { Recovered following Mustang } \mathrm{Q} \\
\text { chromatography (TU) }\end{array}$ & Recovered following buffer exchange (TU) \\
\hline $7.3 \pm 2.0 \times 10^{10}$ & $7.4 \pm 2.3 \times 10^{9}$ & $6.5 \pm 1.8 \times 10^{10}$ & $4.1 \pm 0.6 \times 10^{10}$ & $4.5 \pm 0.8 \times 10^{10}$ \\
\hline
\end{tabular}



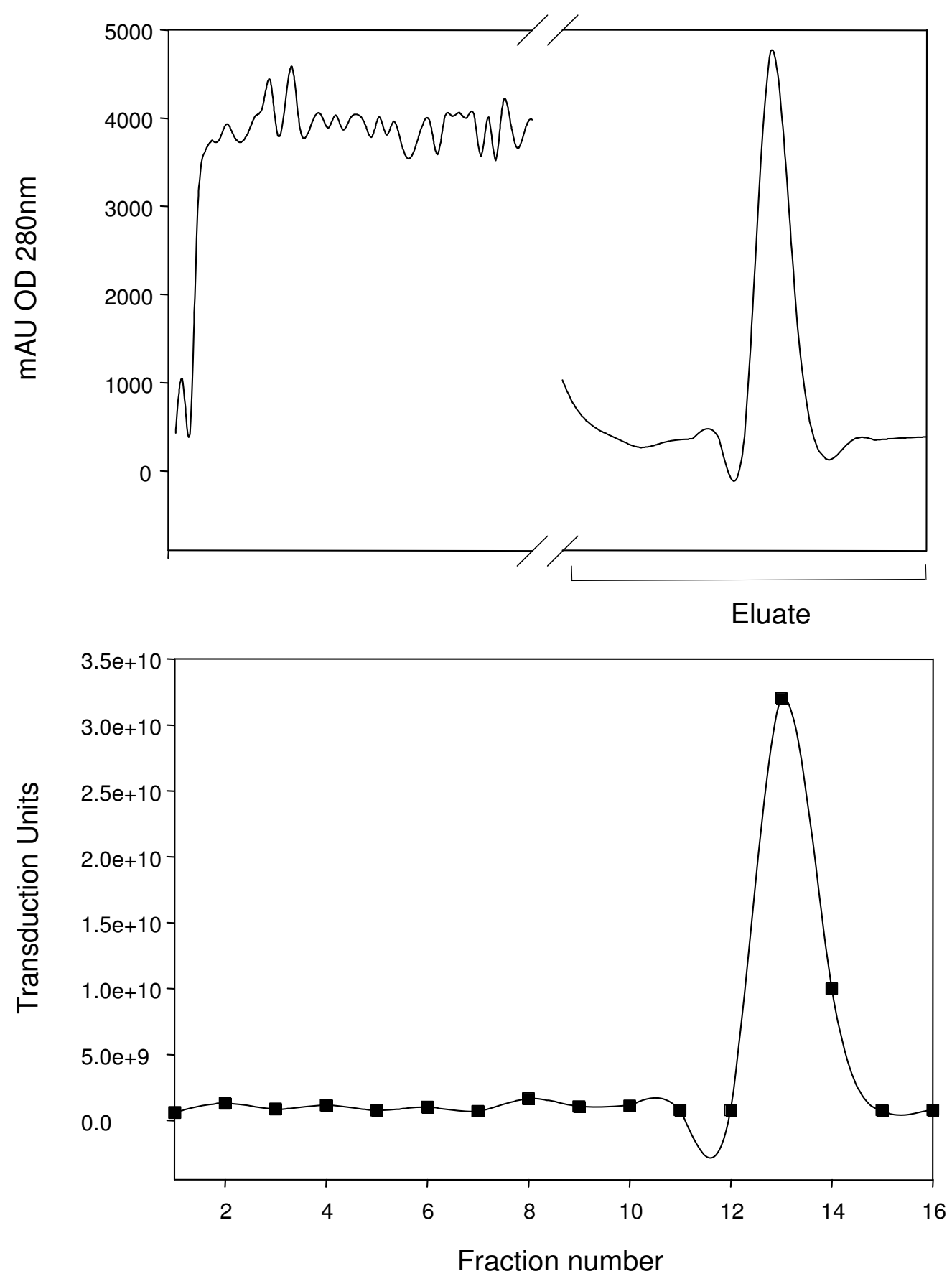

Figure I

Concentration of LV vectors by ion exchange chromatography using Mustang $\mathbf{Q}$ Acrodiscs. A HYPERFlask vesselderived LV vector-containing supernatant $(500 \mathrm{ml})$ was adjusted to $25 \mathrm{mM}$ Tris- $\mathrm{HCl}, \mathrm{pH} 8.0,0.3 \mathrm{M} \mathrm{NaCl}$ and loaded onto a Mustang Q Acrodisc (bed volume $0.18 \mathrm{ml}$ ) at a flow rate of $10 \mathrm{ml} / \mathrm{min}$ for $8 \mathrm{~min}$ using an AKTA purifier HPLC (Amersham Pharmacia) and Unicorn 4.0 Software (Amersham Pharmacia). The Acrodisc's membrane was washed with $2 \mathrm{ml}$ of $25 \mathrm{mM}$ Tris$\mathrm{HCl}, \mathrm{pH} 8.0,0.3 \mathrm{M} \mathrm{NaCl}$ and $\mathrm{LV}$ vectors were eluted with a $10-\mathrm{ml}$ gradient ranging from 0.3 to $1.5 \mathrm{M} \mathrm{NaCl}$ in $25 \mathrm{mM} \mathrm{Tris}-\mathrm{HCl}$, $\mathrm{pH} 8.0$ and $\mathrm{I}-\mathrm{ml}$ fractions were collected. Flow through, wash, and eluate fractions were collected using a FRAC 950 collector (Amersham Pharmacia) and the OD at $280 \mathrm{~nm}$ was recorded (top panel); $\mathrm{mAU}=$ milli-absorbance units. Eluate fractions were immediately processed to analyze vector TU (bottom panel). The total TU for each fraction are presented. 
Table 5: Comparison of lentiviral vector titers using different cell lines

\begin{tabular}{cccc}
\hline Cell line & HOS & $293 \mathrm{~T}$ & HeLa \\
\hline Titer & $3.1 \pm 0.3 \times 10^{10} \mathrm{TU} / \mathrm{ml}$ & $2.0 \pm 0.3 \times 10^{10} \mathrm{TU} / \mathrm{ml}$ & $9.0 \pm 3.4 \times 10^{9} \mathrm{TU} / \mathrm{ml}$ \\
\hline
\end{tabular}

Freshly concentrated LV vector stocks were diluted and aliquots were used to transduce HOS, 293T and HeLa cells as outlined under Materials and Methods. Titers were determined by FACS $(n=3)$. Data are expressed as mean \pm SD.

were combined in $30 \mathrm{ml} 0.25 \mathrm{M} \mathrm{CaCl}_{2}$ and mixed with 30 $\mathrm{ml}$ of $2 \times$ HBS using gentle vortexing. The plasmid DNA/ $\mathrm{CaCl}_{2} / \mathrm{HBS}$ mixture was combined with the remaining medium and transferred back into the HYPERFlask vessel. The total amount of plasmid DNA used was $210 \mu \mathrm{g}$ of the pNL-EGFP/CMV/WPRE $\Delta U 3 \mathrm{LV}$ vector plasmid, $140 \mu \mathrm{g}$ of the $\mathrm{pCD} / \mathrm{NL}-\mathrm{BH}^{*} \Delta \Delta \Delta$ packaging plasmid, and $70 \mu \mathrm{g}$ of the pLTR-G plasmid. The medium was removed $16 \mathrm{~h}$ later and replaced with $550 \mathrm{ml}$ of fresh DMEM/10\% FBS/1\% GlutaMAX. Forty eight $\mathrm{h}$ later, the vector-containing medium was collected and filtered through a $0.45-\mu \mathrm{m}$ pore size filter and stored at $-80^{\circ} \mathrm{C}$. Protein and DNA concentrations in vector supernatants were determined using a Qubit kit (Invitrogen) as recommended by the manufacturer.

\section{Determination of binding capacity of Mustang Q Acrodiscs for lentiviral vectors prepared using $150-\mathrm{cm}^{2}$ dishes or HYPERFlask vessels}

To determine the binding capacity of Mustang Q Acrodiscs (PALL) for LV vectors, $75-\mathrm{ml}$ aliquots of $150-\mathrm{cm}^{2}$ tissue culture dish-derived or HYPERFlask-derived vector supernatants were adjusted to $25 \mathrm{mM}$ Tris- $\mathrm{HCl}, \mathrm{pH} 8.0$, $0.3 \mathrm{M} \mathrm{NaCl}$ and loaded onto a Mustang Q Acrodisc (bed volume $0.18 \mathrm{ml}$ ) at a flow rate of $10 \mathrm{ml} / \mathrm{min}$ for $8 \mathrm{~min}$, using an AKTA purifier HPLC system and Unicorn 4.0 Software (Amersham Pharmacia). After loading, the Acrodisc's membrane was washed with $2 \mathrm{ml}$ of $25 \mathrm{mM}$ Tris$\mathrm{HCl}, \mathrm{pH}$ 8.0, $0.3 \mathrm{M} \mathrm{NaCl}$. LV vectors were eluted with a 10 $\mathrm{ml}$ gradient ranging from 0.3 to $1.5 \mathrm{M} \mathrm{NaCl}$ in $25 \mathrm{mM}$ Tris- $\mathrm{HCl}, \mathrm{pH}$ 8.0. Flow through, wash, and eluate fractions were collected using a FRAC 950 collector (Amersham Pharmacia) and analyzed for vector TU.

\section{Concentration of lentiviral vectors using Mustang $Q$ anion exchange chromatography}

For concentrating LV vectors prepared using HYPERFlask vessels, $500-\mathrm{ml}$ aliquots of vector-containing supernatants were adjusted to $25 \mathrm{mM}$ Tris- $\mathrm{HCl}, \mathrm{pH} 8.0,0.6 \mathrm{M} \mathrm{NaCl}$ and loaded onto a Mustang Q Acrodisc (bed volume $0.18 \mathrm{ml}$ ) attached to an AKTA purifier HPLC system using the system's pump at a flow rate of $10 \mathrm{ml} / \mathrm{min}$ for $50 \mathrm{~min}$. The Acrodisc's membrane was washed with $2 \mathrm{ml}$ of $25 \mathrm{mM}$ Tris-HCl, $\mathrm{pH}$ 8.0, $0.6 \mathrm{M} \mathrm{NaCl}$, and vector particles were eluted with a step gradient ranging from 0.3 to $1.5 \mathrm{M} \mathrm{NaCl}$ in $25 \mathrm{mM}$ Tris- $\mathrm{HCl}, \mathrm{pH}$ 8.0. The flow through, wash, and eluted fractions ( $1 \mathrm{ml}$ per fraction) were collected using a
FRAC 950 collector and immediately analyzed for TU. To desalt the vector samples, the eluted fractions showing the highest TU levels were pooled, loaded onto a $2.0-\mathrm{ml}$ Sepharose CL-4B column (Amersham Pharmacia) equilibrated with Tris-HCl, $\mathrm{pH} 7.4$, and $150 \mathrm{mM} \mathrm{NaCl}$. The column was spun at $500 \times \mathrm{g}$ for $1 \mathrm{~min}$ and the excluded volume was immediately analyzed for TU. The vectors were stored at $-80^{\circ} \mathrm{C}$.

\section{Vector titration using FACS}

To determine vector titers (TU), HOS cells, HeLa cells or 293 cells were plated in 6-well plates at a density of $5 \times$ $10^{4}$ cells per well in DMEM high glucose medium supplemented with $10 \%$ FBS, $1 \%$ GlutaMAX, $1 \%$ Pen/Strep. The next day, the medium was removed and $0.5 \mathrm{ml}$ of medium containing $8 \mu \mathrm{g} / \mathrm{ml}$ polybrene was added. Aliquots of concentrated LV vector preparations diluted 1:500 or of unconcentrated preparations were added. After incubation overnight, the medium containing the vector samples was removed and $2 \mathrm{ml}$ of fresh medium was added to each well. Seventy two $\mathrm{h}$ after vector addition, cells were processed for FACS analysis [28].

\section{Authors' contributions}

$\mathrm{RK}, \mathrm{SP}, \mathrm{MM}$ and JR conceived and designed the experiments. SP and RK performed the LV vector production and RK and MM optimized the Mustang Q anion exchange membrane chromatography steps. JR and RK wrote the manuscript. All authors read and approved the final manuscript.

\section{Acknowledgements}

Support for this work was provided by NIH grants ROI NS044832 and POI HL076100.

\section{References}

I. Wiznerowicz M, Trono D: Harnessing HIV for therapy, basic research and biotechnology. Trends Biotechnol 2005, 23:42-47.

2. Segura MM, Kamen A, Garnier A: Downstream processing of oncoretroviral and lentiviral gene therapy vectors. Biotechnol Adv 2006, 24:32I-337.

3. Sena-Esteves M, Tebbets JC, Steffens S, Crombleholme T, Flake AW: Optimized large-scale production of high titer lentivirus vector pseudotypes. J Virol Methods 2004, I 22: I3|-139.

4. Slepushkin V, Chang N, Cohen R, et al.: Large-scale purification of a lentiviral vector by size exclusion chromatography or Mustang $\mathbf{Q}$ ion exchange capsule. Bioprocess J 2003, 2:89-95.

5. Karolewski BA, Watson DJ, Parente MK, Wolfe JH: Comparison of transfection conditions for a lentivirus vector produced in large volumes. Hum Gene Ther 2003, I 4: I 287-I 296. 
6. Geraerts M, Michiels M, Baekelandt V, Debyser Z, Gijsbers R: Upscaling of lentiviral vector production by tangential flow filtration. J Gene Med 2005, 7: 1299-1310.

7. Segura MM, Garnier A, Durocher Y, Coelho H, Kamen A: Production of lentiviral vectors by large-scale transient transfection of suspension cultures and affinity chromatography purification. Biotechnol Bioeng 2007, 98:789-799.

8. Cronin J, Zhang XY, Reiser J: Altering the tropism of lentiviral vectors through pseudotyping. Curr Gene Ther 2005, 5:387-398.

9. Bartz SR, Rogel ME, Emerman M: Human immunodeficiency virus type I cell cycle control: $\mathrm{Vpr}$ is cytostatic and mediates G2 accumulation by a mechanism which differs from DNA damage checkpoint control. J Virol 1996, 70:2324-233I.

10. Reiser J: Production and concentration of pseudotyped HIV. I-based gene transfer vectors. Gene Therapy 2000, 7:910-9|3.

II. Kobinger GP, Weiner DJ, Yu QC, Wilson JM: Filovirus-pseudotyped lentiviral vector can efficiently and stably transduce airway epithelia in vivo. Nat Biotechnol 200I, 19:225-230.

12. Reiser J, Harmison G, Kluepfel-Stahl S, Brady RO, Karlsson S, Schubert $M$ : Transduction of nondividing cells using pseudotyped defective high- titer HIV type I particles. Proc Natl Acad Sci USA 1996, 93:15266-1527I.

13. Coleman JE, Huentelman MJ, Kasparov S, Metcalfe BL, Paton JF, Katovich MJ, Semple-Rowland SL, Raizada MK: Efficient large-scale production and concentration of HIV-I-based lentiviral vectors for use in vivo. Physiol Genomics 2003, I 2:22 I-228.

14. Koldej R, Cmielewski P, Stocker A, Parsons DW, Anson DS: Optimisation of a multipartite human immunodeficiency virus based vector system; control of virus infectivity and largescale production. J Gene Med 2005, 7:1390-1399.

15. Baekelandt V, Eggermont K, Michiels M, Nuttin B, Debyser Z: Optimized lentiviral vector production and purification procedure prevents immune response after transduction of mouse brain. Gene Ther 2003, 10:1933-1940.

16. Pichlmair A, Diebold SS, Gschmeissner S, Takeuchi Y, Ikeda Y, Collins $M K$, Reis e Sousa C: Tubulovesicular structures within vesicular stomatitis virus $\mathbf{G}$ protein-pseudotyped lentiviral vector preparations carry DNA and stimulate antiviral responses via Toll-like receptor 9. J Virol 2007, 81:539-547.

17. Scherr M, Battmer K, Eder M, Schule S, Hohenberg H, Ganser A, Grez $\mathrm{M}$, Blomer U: Efficient gene transfer into the CNS by lentiviral vectors purified by anion exchange chromatography. Gene Ther 2002, 9: I708-17|4.

18. Yamada K, McCarty DM, Madden VJ, Walsh CE: Lentivirus vector purification using anion exchange HPLC leads to improved gene transfer. Biotechniques 2003, 34:1074-1078. 1080

19. Schauber CA, Tuerk MJ, Pacheco CD, Escarpe PA, Veres G: Lentiviral vectors pseudotyped with baculovirus gp64 efficiently transduce mouse cells in vivo and show tropism restriction against hematopoietic cell types in vitro. Gene Ther 2004, I I:266-275.

20. Ricks DM, Kutner R, Zhang XY, Welsh DA, Reiser J: Optimized lentiviral transduction of mouse bone marrow-derived mesenchymal stem cells. Stem Cells Dev 2008, I7:44I-450.

21. Szymanski SL, Huff KW, Patel AD, et al.: Automated application of a novel high yield, high performance tissue culture flask. JALA 2008, 13:136-144.

22. Kuroda H, Kutner RH, Bazan NG, Reiser J: Simplified lentivirus vector production in protein-free media using polyethylenimine-mediated transfection. J Virol Methods 2009 in press.

23. Lajmi AR, Kutner R, Reiser J: A Membrane Chromatography Application: A Rapid, High Capacity Gene Therapy Vector Purification Tool. In Process Scale Separations for the Biopharmaceutical Industry Edited by: Shukla AA, Etzel MR, Gadam S. Boca Raton, FL: CRC Press; 2007:54 I-564.

24. Marino MP, Kutner RH, Lajmi A, Nochumson S, Reiser J: Development of scaleable purification protocols for lentiviral vectors. Mol Ther 2003, 7:SI78-SI79.

25. Marino MP, Luce MJ, Reiser J: Small- to large-scale production of lentivirus vectors. In Lentivirus Gene Engineering Protocols Volume 229. Edited by: Federico M. Totowa NJ: Humana Press; 2003:43-55.

26. Pear WS, Nolan GP, Scott ML, Baltimore D: Production of hightiter helper-free retroviruses by transient transfection. Proc Natl Acad Sci USA 1993, 90:8392-8396.

27. Zhang XY, La Russia VF, Reiser I: Transduction of bone-marrowderived mesenchymal stem cells by using lentivirus vectors pseudotyped with modified RD I 44 envelope glycoproteins. J Virol 2004, 78:1219-1229.

28. Pluta K, Diehl W, Zhang XY, Kutner R, Bialkowska A, Reiser J: Lentiviral vectors encoding tetracycline-dependent repressors and transactivators for reversible knockdown of gene expression: a comparative study. BMC Biotechnol 2007, 7:41.
Publish with Biomed Central and every scientist can read your work free of charge

"BioMed Central will be the most significant development for disseminating the results of biomedical research in our lifetime. "

Sir Paul Nurse, Cancer Research UK

Your research papers will be:

- available free of charge to the entire biomedical community

- peer reviewed and published immediately upon acceptance

- cited in PubMed and archived on PubMed Central

- yours - you keep the copyright 